\title{
Evaluasi Kesuksesan Website PT Yogyakartas Mega Grafika Saat COVID-19 Menggunakan Model DeLone-McLean
}

\author{
Afifah Rismayanti, Evi Maria*, Hanna Prillysca Chernovita \\ ${ }^{1,2}$ Sistem Informasi, Fakultas Teknologi Informasi, Universitas Kristen Satya Wacana \\ Jl. Dr. O. Notohamidjodjo Blotongan, Sidorejo, Kota Salatiga, Jawa Tengah, Indonesia \\ *e-mail: evi.maria@uksw.edu
}

(received: 11 Juni 2021, revised: 25 Juli 2021, accepted: 5 September 2021)

\begin{abstract}
Abstrak
PT Yogyakartas Mega Grafika adalah Usaha Mikro Kecil Menengah di bidang percetakan yang sudah menggunakan website untuk memasarkan produk dan jasanya. PT Yogyakartas Mega Grafika belum pernah melakukan evaluasi untuk mengukur kesuksesan penggunaan website saat COVID-19, karena penilaian kesuksesan sistem informasi tidak bisa dilakukan secara langsung. Tujuan riset ini adalah untuk melakukan evaluasi kesuksesan penggunaan website di PT Yogyakartas Mega Grafika saat pandemi COVID-19 menggunakan model DeLone-McLean. Model ini telah terbukti secara empiris dapat digunakan untuk menilai kesuksesan sistem informasi. Sampel riset ini adalah pengguna website PT Yogyakartas Mega Grafika saat pandemi, dengan total sampel sebanyak 66 responden. Data dikumpulkan menggunakan kuesioner yang diukur menggunakan skala likert. Data dianalisis menggunakan analisis korelasi Pearson Product Moment. Hasil riset menemukan bukti empiris bahwa penggunaan website di PT Yogyakartas Mega Grafika sukses berperan dalam meningkatkan kinerja perusahaan saat pandemi. Temuan ini juga kokoh dalam analisis tambahan dengan menghitung bobot rata-rata item pengukuran dibagi dengan nilai skala likert. Hasil riset menemukan bahwa bobot ratarata item pengukuran sebesar 4,13 dan hasil persentase kesuksesan adalah 82,6 persen. Ini artinya website PT. Yogyakartas Mega Grafika dinyatakan sangat sukses digunakan meningkatkan kinerja perusahaan saat pandemi COVID-19.
\end{abstract}

Kata kunci: Model DeLone-McLean, evaluasi kesuksesan website, COVID-19.

\begin{abstract}
PT Yogyakartas Mega Grafika is a Micro, Small and Medium Enterprises in the printing sector that has used the website to market its products and services. PT Yogyakartas Mega Grafika has never conducted an evaluation to measure the success rate of using the website during COVID-19, because the success of the information system cannot be assessed directly. The purpose of this research is to evaluate the success of using the website at PT Yogyakartas Mega Grafika during the COVID-19 pandemic using the DeLone-McLean models. This model has been empirically proven to be used to assess the success of information systems. The sample of this research is users of the PT Yogyakartas Mega Grafika website during the pandemic, with a total sample of 66 respondents. Data were collected using a questionnaire which was measured using a scale Likert. Data were analyzed using correlation analysis Pearson Product Moment. The results of the research found empirical evidence that the use of the website at PT Yogyakartas Mega Grafika successfully played a role in improving company performance during the pandemic. This finding is also robust in the additional analysis by calculating the average weight of the measurement items divided by the scale value Likert. The results of the research found that the average weight of the measurement items was 4.13 and the percentage of success was 82.6 percent. This means that the website of PT. Yogyakartas Mega Grafika was declared very successful in being used to improve company performance during the COVID-19 pandemic.
\end{abstract}

Keywords: DeLone-McLean Models, success evaluation website, COVID-19 


\section{Pendahuluan}

Pemberlakuan kebijakan pembatasan sosial dalam upaya pencegahan penyebaran virus corona di Indonesia, membawa dampak pada turunnya aktivitas ekonomi dan perdagangan. Akibatnya, pertumbuhan ekonomi Indonesia Triwulan II 2020 mengalami kontraksi sebesar -5,32 persen dan membawa Indonesia pada zona krisis. Pembatasan sosial dilakukan dengan cara mengurangi frekuensi interaksi langsung antara penjual dan pembeli di pasar. Padahal sebagian besar Usaha Mikro Kecil Menengah (UMKM) di Indonesia masih mengandalkan toko fisik dan metode penjualan secara langsung. Saat pandemi COVID-19, UMKM mengalami penurunan kinerja. Hasil survei Pusat Penelitian Ekonomi LIPI [1] menemukan secara umum, pandemi COVID-19 menyebabkan penurunan keuntungan usaha lebih besar dari 75 persen. Ini karena biaya produksi cenderung meningkat sedangkan penjualan usaha mengalami penurunan tajam. Kondisi ini membuat UMKM tidak lagi bisa menjadi sektor andalan untuk menopang pertumbuhan ekonomi di Indonesia, seperti saat krisis ekonomi pada periode-periode sebelumnya, yaitu tahun 1997-1998 dan tahun 2008-2009 [2].

Menariknya, hasil survei Pusat Penelitian Ekonomi LIPI [1] menemukan bahwa penurunan keuntungan usaha lebih dari 75 persen dialami terbanyak oleh UMKM yang masih menggunakan metode penjualan secara langsung daripada UMKM yang melakukan penjualan secara online dan/atau UMKM yang menggunakan metode gabungan, yaitu penjualan secara langsung dan online. Ini artinya, UMKM yang sudah mentransformasi bisnisnya dengan memanfaatkan teknologi informasi dan komunikasi (TIK), khususnya dalam bidang pemasaran adalah UMKM yang dapat bertahan saat pandemi ini. Less contact economics, yaitu pola ekonomi yang minim tatap muka dengan memanfaatkan TIK dalam bisnis, adalah bentuk kenormalan baru di saat pandemi. Proses transformasi bisnis dari metode konvensional ke basis digital dilakukan secara menyeluruh pada seluruh proses bisnis organisasi, sehingga UMKM dapat kembali bangkit dan menggerakkan perekonomian nasional [3].

PT Yogyakartas Mega Grafika adalah salah satu UMKM sektor industri kreatif bidang percetakan yang sudah mengimplementasikan TIK dalam proses bisnis serta pemasarannya. PT Yogyakartas Mega Grafika memiliki website perusahaan yang digunakan sebagai media atau sarana komunikasi dengan pelanggan. Website PT Yogyakartas Mega Grafika dapat diakses di www.yogyakartas.com. Melalui website tersebut pelanggan dapat melihat produk yang ditawarkan, produk terbaru, informasi terkait cara pemesanan, jam buka, layanan serta pengiriman dan juga dapat menghubungi customer service untuk menanyakan terkait produk atau juga bisa melakukan pemesanan produk. Namun, apakah penggunaan website di PT Yogyakartas Mega Grafika memiliki pengaruh pada peningkatan kinerja perusahaan khususnya pada saat pandemi COVID-19 ini, masih merupakan pertanyaan riset yang belum terjawab. PT Yogyakartas Mega Grafika belum pernah melakukan evaluasi kesuksesan penggunaan website. Kondisi ini membuat riset untuk mengevaluasi kesuksesan penggunaan website di PT Yogyakartas Mega Grafika saat pandemi menjadi menarik dilakukan.

Penilaian kesuksesan implementasi sistem informasi yang efektif, sulit dilakukan secara langsung [4]. Kondisi ini mendorong riset terdahulu tentang pengembangan model untuk menilai kesuksesan banyak dilakukan [5][6][7][8]. Namun, model kesuksesan sistem informasi DeLone-McLean mendapat perhatian lebih ketika peneliti mencari dukungan empiris untuk menjelaskan kesuksesan penggunaan sistem informasi baik itu di pemerintah daerah, seperti riset [9][10][11] maupun di perusahaan, seperti riset [12][13][14][15]. Riset-riset terdahulu tersebut telah menemukan bukti empiris bahwa model DeLone-McLean dapat digunakan untuk mengukur kesuksesan sistem informasi. Ini artinya model DeLone-McLean dapat digunakan oleh PT Yogyakartas Mega Grafika ketika akan mengevaluasi kesuksesan penggunaan website perusahaan saat pandemi COVID-19. Ada lima indikator untuk mengukur kesuksesan sistem informasi menurut model DeLone-McLean, antara lain kualitas sistem, kualitas informasi, kualitas layanan, kepuasan penggunan dan kebermanfaatan sistem [6]. Oleh sebab itu, riset ini akan mencoba mengevaluasi kesuksesan penggunaan website di PT Yogyakartas Mega Grafika saat COVID-19 menggunakan model DeLone-McLean. Tujuannya, agar ditemukan bukti empiris hubungan antara penggunaan website dengan kinerja PT Yogyakartas Mega Grafika saat pandemi COVID-19. 


\section{Tinjauan Literatur}

Model DeLone-McLean awal dikembangkan tahun 1992. Model ini mengidentifikasi kesuksesan sistem informasi dapat diukur dari keberhasilan teknis, yaitu kualitas sistem, keberhasilan semantik, yaitu kualitas informasi dan penggunaan sistem, sedangkan keberhasilan efektivitas diukur dengan kepuasan pengguna, dampak individu dan dampak organisasi. Model ini kemudian diperbarui tahun 2003, kualitas sistem informasi memiliki tiga dimensi utama, yaitu kualitas sistem, kualitas informasi dan kualitas layanan. Masing-masing dimensi harus diukur atau dikontrol secara terpisah, karena secara tunggal atau bersama-sama akan mempengaruhi keinginan untuk menggunakan dan kepuasan pengguna. Sedangkan, variabel dampak individu dan organisasi berubah menjadi manfaat bersih (net benefit) [6].

Model DeLone-McLean sudah digunakan oleh beberapa riset terdahulu untuk mengukur kesuksesan penggunaan sistem informasi baik di pemerintah daerah maupun di perusahaan. Riset [9] dan [10] telah menemukan bukti bahwa model DeLone-McLean dapat digunakan untuk mengukur kesuksesan implementasi e-government di pemerintah Kabupaten Grobogan dan Kota Pekalongan. Riset [11] menemukan bahwa tingkat penerapan e-Government LAPOR sebesar 73,4 persen, artinya aplikasi LAPOR sukses digunakan. Riset [12] menemukan implementasi sistem informasi absensi online di STIKOM Bali masih masuk dalam kategori cukup baik. Ini karena hasil evaluasi menemukan bahwa kualitas sistem dan kualitas layanan tidak terbukti berpengaruh pada penggunaan sistem absensi online. Riset [13] menemukan bahwa kualitas sistem, informasi dan layanan berpengaruh pada kepuasan pengguna layanan mobile banking. Riset [14] menemukan bahwa kualitas sistem dan kualitas informasi berpengaruh signifikan terhadap kinerja kesuksesan penggunaan sistem informasi smart prodi, sehingga penggunaannya memberikan manfaat bersih bagi prodi. Riset [15] menemukan bahwa kualitas sistem, informasi, layanan, kepuasan pelanggan dan net benefit dari sistem informasi kesehatan, yaitu www.homedika.com masuk dalam kategori tinggi, sedangkan penggunaan sistem masih dalam kategori cukup.

Riset [16] menemukan bahwa tiga faktor utama yang mempengaruhi kepuasan pengguna pada sistem informasi yaitu kualitas informasi, kualitas sistem, dan kebermanfaatan sistem berdasarkan sudut pandang pengguna e-learning pada salah satu perguruan tinggi di Bandung. Riset [17] menemukan bahwa terdapat pengaruh yang signifikan dari kualitas informasi, kualitas sistem dan dan kualitas layanan $e$-biling terhadap manfaat yang diterima berdasarkan penggunaan sistem $e$-biling yang intensif di Kota Semarang, namun tingkat kepuasan yang dirasakan oleh wajib pajak belum dapat merepresentasikan manfaat dari pengaruh kualitas sistem, kualitas sistem, dan kualitas layanan atas penggunaan sistem e-biling dan menurut badan wajib pajak di kota semarang manfaat dari kualitas sistem dan layanan yang disajikan sistem e-billing dianggap kurang baik. Riset [18] menemukan bahwa dalam relasi antara kualitas informasi dan kualitas layanan terhadap manfaat bersih terdapat variabel intervening yang merupakan kepuasan pengguna akan tetapi dalam relasi antara kualitas sistem terhadap manfaat bersih tidak terdapat variabel intervening yang ditujukan untuk kepuasan pengguna pada system e-faktur pada KPP Pratama Metro.

Perbedaan riset ini dengan riset sebelumnya terletak pada bidang yang dievaluasi. Riset ini melakukan evaluasi pada UMKM sektor kreatif Indonesia di bidang percetakan. PT Yogyakartas Mega Grafika belum pernah melakukan evaluasi keefektifan penggunaan website dan kinerja perusahaan khususnya saat pandemi COVID-19. Riset sebelumnya meneliti pada saat kondisi normal, sedangkan riset saat ini pada saat pandemi. Riset ini memiliki dua kontribusi. Pertama, berkontribusi bagi pengembangan ilmu di bidang sistem informasi karena menyediakan bukti empiris hubungan antara penggunaan website dengan kinerja organisasi khususnya pada saat kondisi pandemi COVID19 yang melanda di Indonesia. Kedua, bagi perusahaan karena hasil riset memberikan informasi keefektifan penggunaan website saat pandemi dan hubungannya dengan kinerja organisasi. Hasil riset ini juga memberikan informasi kepada perusahaan tentang pentingnya penerapan sistem informasi saat pandemi COVID-19 bagi perusahaan, sehingga sistem informasi perlu dilakukan pengelolaan dengan baik. 


\section{Metode Penelitian}

Riset ini menggunakan jenis penelitian kuantitatif. Metode kuantitatif memiliki sifat yang dapat diklasifikasikan, teramati, konkrit serta terukur [19]. Metode ini dipilih karena riset ini bertujuan untuk menunjukkan hubungan antar variabel, mencari generalisasi yang mempunyai nilai prediktif, dan menguji sebuah teori, serta instrumen yang digunakan berupa wawancara dan kuesioner dengan data-data berupa angka dan diolah menggunakan statistik. Populasi dalam penelitian ini adalah pengunjung website PT Yogyakartas Mega Grafika. Sampel riset ini menggunakan metode purposive sampling dengan kriteria, pengunjung website PT Yogyakartas Mega Grafika harus mengisi seluruh item dalam kuesioner dengan lengkap. Total sampel riset ini ada 66 responden dengan jangka waktu pengumpulan mulai dari 1 Maret-6 Mei 2021. Data dikumpulkan menggunakan kuesioner online yang disebarluaskan melalui google form kepada seluruh pengguna website.

\section{Variabel Operasional dan Pengukuran Variabel}

Variabel riset ini, antara lain kualitas sistem, kualitas informasi, kualitas layanan, penggunaan, kepuasan pengguna dan manfaat bersih. Variabel-variabel tersebut, tidak dapat diukur secara langsung, sehingga butuh indikator untuk mengukurnya [6]. Riset ini menggunakan indikator yang dikembangkan dalam riset [6]. Pertanyaan setiap indikator dalam kuesioner diadaptasi dari riset [6], [10] dan [20]. Riset ini menggunakan skala likert 5, yaitu skor 1 untuk sangat tidak setuju (STS), skor 2 untuk tidak (TS) setuju, skor 3 untuk netral (N), skor 4 untuk setuju (S) dan skor 5 untuk sangat setuju (SS). Operasionalisasi variabel riset ini disajikan pada Tabel 1.

Tabel 1. Operasionalisasi Variabel Riset

\begin{tabular}{|c|c|c|}
\hline VARIABEL & INDIKATOR & PERTANYAAN \\
\hline \multirow[t]{5}{*}{$\begin{array}{c}\text { Kualitas } \\
\text { Sistem }(\mathrm{KS})\end{array}$} & $\begin{array}{l}\text { KS1 Kemampuan } \\
\text { adaptasi }\end{array}$ & $\begin{array}{l}\text { 1. Website dapat diakses melalui perangkat dan platform yang } \\
\text { beragam, seperti Google Chrome, Mozilla Firefox, IE, } \\
\text { Smartphone, Laptop, dll. }\end{array}$ \\
\hline & KS2 Ketersediaan & $\begin{array}{l}\text { 2. Website dapat menyajikan informasi mengenai perusahaan } \\
\text { dan produk sesuai data yang sebenarnya. }\end{array}$ \\
\hline & KS3 Keandalan & $\begin{array}{l}\text { 3. Website dapat diandalkan (dipercaya) dalam memberikan } \\
\text { informasi mengenai perusahaan dan produk. }\end{array}$ \\
\hline & KS4 Waktu respon & $\begin{array}{l}\text { 4. Website dapat dengan cepat menampilkan informasi } \\
\text { mengenai perusahaan dan produk. }\end{array}$ \\
\hline & KS5 Kegunaan & $\begin{array}{l}\text { 5. Pengunjung dapat menggunakan website dalam mencari } \\
\text { kebutuhan terkait mengenai perusahaan dan produk. }\end{array}$ \\
\hline \multirow{5}{*}{$\begin{array}{l}\text { Kualitas } \\
\text { Informasi } \\
\quad(\mathrm{KI})\end{array}$} & KI1 Kelengkapan & $\begin{array}{l}\text { 6. Pengguna website dapat memperoleh data mengenai } \\
\text { perusahaan dan produk yang lengkap. }\end{array}$ \\
\hline & KI2 Mudah dipahami & $\begin{array}{l}\text { 7. Informasi yang ditampilkan merupakan data mengenai } \\
\text { perusahaan dan produk yang mudah dipahami. }\end{array}$ \\
\hline & KI3 Personalisasi & $\begin{array}{l}\text { 8. Tampilan dari informasi mengenai perusahaan dan produk } \\
\text { yang disajikan menarik untuk dilihat. }\end{array}$ \\
\hline & KI 4 Relevansi & $\begin{array}{l}\text { 9. Informasi yang ada merupakan data mengenai perusahaan } \\
\text { dan produk yang saling berkaitan. }\end{array}$ \\
\hline & KI 5 Keamanan & $\begin{array}{l}\text { 10. Informasi mengenai perusahaan dan produk yang diberikan } \\
\text { terjamin keamanannya. }\end{array}$ \\
\hline \multirow{3}{*}{$\begin{array}{l}\text { Kualitas } \\
\text { Layanan } \\
\text { (KL) }\end{array}$} & KL1 Jaminan & $\begin{array}{l}\text { 11. Saya mendapat solusi terhadap permasalahan mengenai } \\
\text { perusahaan dan produk pada saat mengakses website. }\end{array}$ \\
\hline & KL2 Empati & $\begin{array}{l}\text { 12. Saya merasa terbantu terhadap kemudahan saat mengakses } \\
\text { data mengenai perusahaan dan produk. }\end{array}$ \\
\hline & KL3 Daya tanggap & $\begin{array}{l}\text { 13. Respon layanan website cepat tanggap dalam memberi } \\
\text { bantuan mengenai perusahaan dan produk. }\end{array}$ \\
\hline \multirow[t]{2}{*}{$\begin{array}{l}\text { Penggunaan } \\
\text { (P) }\end{array}$} & P1 Sifat penggunaan & $\begin{array}{l}\text { 14. Saya menggunakan fungsi yang ada pada website untuk } \\
\text { mencapai tujuan mengenai perusahaan dan produk, seperti } \\
\text { layanan chat customer service. }\end{array}$ \\
\hline & P2 Pola navigasi & 15. Saya menggunakan fungsi yang ada pada website sesuai \\
\hline
\end{tabular}




\begin{tabular}{|c|c|c|}
\hline & & $\begin{array}{l}\text { dengan alur mengenai perusahaan dan produk, seperti fitur } \\
\text { pencarian. }\end{array}$ \\
\hline & P3 Jumlah kunjungan & $\begin{array}{l}\text { 16. Dalam kurun waktu sebulan dapat melakukan kunjungan } \\
\text { website lebih dari } 4 \text { kali. }\end{array}$ \\
\hline & $\begin{array}{l}\text { P4 Jumlah transaksi yang } \\
\text { dilakukan }\end{array}$ & $\begin{array}{l}\text { 17. Dalam kurun waktu sebulan dapat melakukan pemesanan } \\
\text { produk lebih dari } 4 \text { kali. }\end{array}$ \\
\hline \multirow[t]{3}{*}{$\begin{array}{l}\text { Kepuasan } \\
\text { Pengguna } \\
\quad(\text { KP) }\end{array}$} & KP1 Pembelian berulang & $\begin{array}{l}\text { 18. Saya merasa puas dengan informasi mengenai perusahaan } \\
\text { dan produk pada website sehingga mendorong melakukan } \\
\text { pembelian kembali. }\end{array}$ \\
\hline & KP2 Kunjungan berulang & $\begin{array}{l}\text { 19. Saya merasa puas terhadap informasi yang disajikan pada } \\
\text { website sehingga terdorong melakukan kunjungan kembali. }\end{array}$ \\
\hline & KP3 Survei pengguna & $\begin{array}{l}\text { 20. Saya merasa perlu adanya fitur pada website untuk } \\
\text { memberikan peninjauan terhadap produk yang ada, seperti } \\
\text { rating dan ulasan. }\end{array}$ \\
\hline \multirow[t]{5}{*}{$\begin{array}{c}\text { Manfaat } \\
\text { Bersih (MB) }\end{array}$} & MB1 Hemat biaya & $\begin{array}{l}\text { 21. Website dapat mengurangi pengeluaran pengguna, seperti } \\
\text { biaya transportasi untuk ke outlet. }\end{array}$ \\
\hline & MB2 Perluasan pasar & $\begin{array}{l}\text { 22. Website dapat memperluas pemasaran, pembelian produk } \\
\text { tanpa datang ke outlet. }\end{array}$ \\
\hline & $\begin{array}{l}\text { MB3 Penjualan } \\
\text { tambahan inkremental }\end{array}$ & $\begin{array}{l}\text { 23. Dengan adanya website, perusahaan dan penjualan produk } \\
\text { memiliki nilai tambah. }\end{array}$ \\
\hline & $\begin{array}{l}\text { MB4 Pengurangan biaya } \\
\text { pencarian produk }\end{array}$ & $\begin{array}{l}\text { 24. Website membuat proses pencarian produk menjadi lebih } \\
\text { efektif, seperti informasi produk tanpa datang ke outlet. }\end{array}$ \\
\hline & MB5 Hemat waktu & $\begin{array}{l}\text { 25. Website mempercepat dalam pencarian mengenai } \\
\text { perusahaan maupun produk yang dibutuhkan. }\end{array}$ \\
\hline
\end{tabular}

\section{Langkah Penyusunan Hipotesis}

Kualitas sistem (KS) merupakan performa dari sistem, fokus pada kualitas sistem dalam menyediakan kebutuhan informasi bagi pengguna. Kualitas sistem merujuk pada seberapa baik kemampuan perangkat keras, perangkat lunak, kebijakan, dan prosedur dari sistem informasi yang ada [9]. Kualitas sistem dinilai dari kegunaan, ketersediaan, keandalan, kemampuan beradaptasi serta waktu responnya [6]. Jika kualitas sistem mempengaruhi kepuasan pengguna maka pengguna akan melakukan pembelian produk atau transaksi lainnya melalui website perusahaan, sedangkan jika mempengaruhi penggunaan maka pengguna akan menggunakan fungsi yang ada seperti fitur-fiturnya dan akan kembali mengunjungi website perusahaan. Dalam rangka menguji hubungan kualitas sistem dan kepuasan serta penggunaan website di PT Yogyakartas Mega Grafika, maka hipotesis pertama riset ini dinyatakan sebagai berikut.

$\mathrm{H}_{1 \mathrm{a}}$. Kualitas sistem akan berpengaruh positif terhadap kepuasan pengguna website

$\mathrm{H}_{1 \mathrm{~b}}$. Kualitas sistem akan berpengaruh positif terhadap penggunaan website

Kualitas informasi (KI) merupakan aspek dari tingkat baik buruknya nilai sebuah informasi, yang memiliki beberapa aspek seperti hasil pemrosesan sistem informasi, nilai, manfaat, kebutuhan serta kaitan atas informasi yang dihasilkan [9]. Kualitas informasi dinilai dari isi konten yang memiliki personalisasi atau tampilan yang mudah dipahami, lengkap, aman dan saling berkaitan antar informasi [6]. Jika kualitas informasi mempengaruhi kepuasan pengguna maka pengguna akan melakukan transaksi karena tertarik dengan konten informasi yang ditampilkan di website perusahaan, sedangkan jika mempengaruhi penggunaan maka pengguna akan kembali mengunjungi website perusahaan dan menggunakan fungsi yang ada seperti fitur-fiturnya. Dalam rangka menguji hubungan kualitas informasi dan kepuasan serta penggunaan website di PT Yogyakartas Mega Grafika, maka hipotesis kedua riset ini dinyatakan sebagai berikut.

$\mathrm{H}_{2 \mathrm{a}}$. Kualitas informasi akan berpengaruh positif terhadap kepuasan pengguna website.

$\mathrm{H}_{2 \mathrm{~b}}$. Kualitas informasi akan berpengaruh positif terhadap penggunaan website.

Kualitas layanan (KL) merupakan usaha untuk mewujudkan akurasi dalam penyampaian layanan informasi, demi memenuhi harapan pengguna beserta keperluan dan hal yang dikehendaki pengguna [9]. Kualitas layanan dinilai dari cepatnya pelayanan, kepeduliannya, serta solusi yang diberikan [6]. 
Jika kualitas layanan mempengaruhi kepuasan pengguna maka pengguna akan melakukan konsultasi atau bertanya perihal perusahaan atau produk melalui website perusahaan, sedangkan jika mempengaruhi penggunaan maka pengguna akan menggunakan fungsi yang ada seperti fitur chat customer service pada website perusahaan. Dalam rangka menguji hubungan kualitas layanan dan kepuasan serta penggunaan website di PT Yogyakartas Mega Grafika, maka hipotesis ketiga riset ini dinyatakan sebagai berikut.

$\mathrm{H}_{3 \mathrm{a}}$. Kualitas layanan akan berpengaruh positif terhadap kepuasan pengguna website.

$\mathrm{H}_{3 \mathrm{~b}}$. Kualitas layanan akan berpengaruh positif terhadap penggunaan website.

Penggunaan sistem $(\mathrm{P})$ merupakan pemahaman dari penjelasan terkait kegunaan sistem mengenai kepercayaan pengguna pada suatu proses pengambilan keputusan. Sistem informasi dapat dikatakan berguna apabila dipercaya oleh penggunanya, maka sistem tersebut akan terus digunakan, dan apabila sistem informasi kurang berguna maka pengguna cenderung tidak akan menggunakannya kembali [9]. Penggunaan sistem dinilai mulai dari jumlah kunjungan ke website, navigasi website, pengambilan informasi, hingga pelaksanaan transaksi [6]. Jika penggunaan sistem mempengaruhi kepuasan pengguna maka pengguna akan percaya sehingga melakukan pembelian kembali melalui website, sedangkan jika mempengaruhi manfaat bersih maka pengguna akan merasa terbantu dengan adanya website karena dapat mempercepat dalam mendapatkan informasi mengenai produk dan meminimalisir tingkat kesalahan data yang diperoleh. Dalam rangka menguji hubungan penggunaan website PT Yogyakartas Mega Grafika dan kepuasan pengguna serta manfaat bersih, maka hipotesis keempat riset ini, dinyatakan sebagai berikut.

$\mathrm{H}_{4 \mathrm{a}}$. Penggunaan website akan mempengaruhi kepuasan pengguna website.

$\mathrm{H}_{4 \mathrm{~b}}$. Penggunaan website akan mempengaruhi manfaat bersih PT Yogyakartas Mega Grafika.

Kepuasan pengguna (KP) merupakan persepsi kepercayaan pengguna terhadap sistem informasi yang sudah ada telah memiliki informasi sesuai dengan kebutuhan pengguna [9]. Kepuasan pengguna dinilai dari opini pengguna tentang website, serta mencakup keseluruhan pengalaman pengguna berdasarkan pengambilan informasi melalui pembelian, pembayaran, penerimaan, dan layanan melalui website [6]. Jika kepuasan pengguna mempengaruhi penggunaan sistem, maka pengguna akan melakukan transaksi produk secara berulang di perusahaan, sedangkan jika mempengaruhi manfaat bersih maka perusahaan mendapatkan nilai tambah dan kinerja perusahaan meningkat, begitu juga untuk pengguna website dapat menghemat waktu dalam mencari informasi dan menjadi lebih efektif. Dalam rangka menguji hubungan kepuasan pengguna website PT Yogyakartas Mega Grafika dan penggunaan website serta manfaat bersih, maka hipotesis kelima riset ini, dinyatakan sebagai berikut.

$\mathrm{H}_{5 \mathrm{a}}$. Kepuasan pengguna website akan mempengaruhi penggunaan website.

$\mathrm{H}_{5 \mathrm{~b}}$. Kepuasan pengguna website akan mempengaruhi manfaat bersih PT Yogyakartas Mega Grafika.

Manfaat bersih (MB) merupakan dampak yang didapatkan oleh pengguna dan organisasi dengan adanya sistem informasi [15]. Dampak Penggunaan merupakan hal terpenting dalam mengukur keberhasilan sistem informasi, karena cakupannya berupa dampak positif atau negatif [6]. Jika dampak penggunaan dapat mempermudah pengguna dalam proses pencarian produk di website, tentunya dapat mempengaruhi kepuasan pengguna. Ini membuat pengguna akan kembali menggunakan website, sedangkan jika mempengaruhi penggunaan sistem maka pengguna telah menggunakan fungsi yang ada pada website dengan baik. Dalam rangka menguji hubungan manfaat bersih dan kepuasan serta penggunaan website di PT Yogyakartas Mega Grafika, maka hipotesis keenam riset ini, dinyatakan sebagai berikut.

$\mathrm{H}_{6 \mathrm{a}}$. Manfaat bersih akan berpengaruh positif terhadap kepuasan pengguna website

$\mathrm{H}_{6 \mathrm{~b}}$. Manfaat bersih akan berpengaruh positif terhadap penggunaan website. 


\section{Metode Analisis}

Alat analisis riset ini ada tiga. Pertama, pengujian validitas dan reliabilitas. Uji validitas dilakukan untuk mengukur kebenaran dari tiap pernyataan pada kuesioner. Uji validitas riset ini menggunakan Pearson Product Moment, sama seperti riset [14]. Setiap item kuesioner dikatakan valid jika nilai Sig. $<0,05$ sedangkan dinyatakan tidak valid jika nilai Sig. $>0,05$ [21]. Sedangkan, uji reliabilitas dilakukan untuk mengetahui tingkat konsistensi atau keandalan dari tiap pernyataan pada kuesioner. Uji reliabilitas riset ini menggunakan Cronbach's Alpha, sama seperti riset [14]. Jika nilai Cronbach's Alpha>0,6 maka dinyatakan reliabel sedangkan jika nilai Cronbach's Alpha<0,6 maka dinyatakan tidak reliabel [22]. Kedua, pengujian hipotesis menggunakan analisis korelasi Pearson Product Moment, sama seperti yang digunakan dalam riset [16]. Pengujian hipotesis dilakukan dalam rangka mengukur tingkat kesuksesan penggunaan website di PT Yogyakartas Mega Grafika selama pandemi COVID-19 menggunakan model DeLone-McLean [6]. Kesuksesan website di PT Yogyakartas Mega Grafika diukur dari kualitas sistem, kualitas informasi, kualitas layanan, penggunaan, kepuasan pengguna dan manfaat bersih. Hipotesis didukung jika nilai Sig. $<0,05$ dan sebaliknya. Jika nilai Sig.>0,05 maka hipotesis tidak didukung [18][19]. Tingkatan derajat hubungan korelasi disajikan pada Tabel 2. Ketiga, pengujian tambahan. Tujuannya untuk melihat apakah hasil pengujian kesuksesan website di PT Yogyakartas Mega Grafika yang sudah dilakukan pada tahap sebelumnya, konsisten hasilnya jika diuji menggunakan metode yang berbeda. Pengujian tambahan ini dilakukan menggunakan rumus dan perhitungan seperti yang digunakan dalam riset [11]. Persentase kesuksesan dihitung dari bobot rata-rata item pengukuran dibagi dengan nilai skala likert.

Tabel 2. Tingkat Korelasi Hubungan

\begin{tabular}{cl}
\hline Interval Koefisien & \multicolumn{1}{c}{ Tingkatan Hubungan } \\
\hline $0,00-0,20$ & Tidak ada korelasi \\
$0,21-0,40$ & Korelasi lemah \\
$0,41-0,60$ & Korelasi sedang \\
$0,61-0,80$ & Korelasi kuat \\
$0,81-1,00$ & Korelasi sangat kuat \\
\hline
\end{tabular}

\section{Hasil dan Pembahasan}

\section{Hasil Pengujian Validitas dan Reliabilitas}

Pengujian validitas riset ini dilakukan menggunakan Pearson Product Moment. Tabel 3 menyajikan hasil uji validitas riset ini. Berdasarkan hasil uji validitas ditemukan 25 item pertanyaan kuesioner riset ini memiliki nilai signifikansi $<0,05$. Ini artinya semua item pernyataan dari variabel kualitas sistem, kualitas informasi, kualitas layanan, penggunaan, kepuasaan pengguna dan manfaat bersih dalam riset ini dinyatakan valid dan dapat digunakan pada proses pengujian selanjutnya.

Tabel 3. Hasil Uji Validitas

\begin{tabular}{cccccc}
\hline No. Item & Rhitung & Sig. & No. Item & Rhitung & Sig. \\
\hline 1 & 0,777 & 0,000 & 14 & 0,558 & 0,000 \\
2 & 0,874 & 0,000 & 15 & 0,738 & 0,000 \\
3 & 0,895 & 0,000 & 16 & 0,890 & 0,000 \\
4 & 0,854 & 0,000 & 17 & 0,891 & 0,000 \\
5 & 0,843 & 0,000 & 18 & 0,891 & 0,000 \\
6 & 0,911 & 0,000 & 19 & 0,882 & 0,000 \\
7 & 0,778 & 0,000 & 20 & 0,671 & 0,000 \\
8 & 0,796 & 0,000 & 21 & 0,901 & 0,000 \\
9 & 0,846 & 0,000 & 22 & 0,864 & 0,000 \\
10 & 0,888 & 0,000 & 23 & 0,917 & 0,000 \\
11 & 0,884 & 0,000 & 24 & 0,850 & 0,000 \\
12 & 0,906 & 0,000 & 25 & 0,846 & 0,000 \\
13 & 0,885 & 0,000 & & & \\
\hline Sumber: data primer yang diolah &
\end{tabular}

Pengujian reliabilitas dilakukan menggunakan Cronbach's Alpha. Tabel 4 menyajikan hasil uji reliabilitas riset ini. Berdasarkan hasil uji reliabilitas menemukan bahwa seluruh variabel riset ini 
memiliki nilai Cronbach's Alpha >0,6. Ini artinya tiap pertanyaan kuesioner terkait dengan variabel kualitas sistem, kualitas informasi, kualitas layanan, penggunaan, kepuasan pengguna dan manfaat bersih dinyatakan reliabel dan dapat digunakan untuk proses pengujian selanjutnya.

Tabel 4. Hasil Uji Reliabilitas

\begin{tabular}{lccc}
\hline \multicolumn{1}{c}{ Variabel } & Cronbach's Alpha & Jumlah Item & Keterangan \\
\hline Kualitas Sistem (KS) & 0,903 & 5 & Reliabel \\
Kualitas Informasi (KI) & 0,900 & 5 & Reliabel \\
Kualitas Layanan (KL) & 0,869 & 3 & Reliabel \\
Penggunaan (P) & 0,775 & 4 & Reliabel \\
Kepuasan Pengguna (KP) & 0,755 & 3 & Reliabel \\
Manfaat Bersih (MB) & 0,924 & 5 & Reliabel \\
\hline
\end{tabular}

Sumber: data primer yang diolah

\section{Hasil Pengujian Hipotesis}

Riset ini menggunakan analisis korelasi Pearson Product Moment, ketika melakukan pengujian hipotesis sama seperti yang digunakan dalam riset [16]. Ada enam hipotesis yang diuji dalam riset ini. Hasil pengujian hipotesis riset ini disajikan pada Tabel 5.

Tabel 5. Hasil Uji Hipotesis

\begin{tabular}{lcccc}
\hline \multicolumn{1}{c}{ Hipotesis } & Sign & $\begin{array}{c}\text { Keterangan } \\
\text { Hipotesis }\end{array}$ & $\begin{array}{c}\text { Koefisien } \\
\text { PPM }\end{array}$ & $\begin{array}{c}\text { Keterangan } \\
\text { Koefisien PPM }\end{array}$ \\
\hline $\mathrm{H}_{1 \mathrm{a}}$ Kualitas Sistem-Kepuasan Pengguna & 0,000 & Berkorelasi & 0,806 & Sangat Kuat, Positif \\
$\mathrm{H}_{1 \mathrm{~b}}$ Kualitas Sistem-Penggunaan Website & 0,000 & Berkorelasi & 0,676 & Kuat, Positif \\
$\mathrm{H}_{2 \mathrm{a}}$ Kualitas Informasi-Kepuasan Pengguna & 0,000 & Berkorelasi & 0,858 & Sangat Kuat, Positif \\
$\mathrm{H}_{2 \mathrm{~b}}$ Kualitas Informasi-Penggunaan Website & 0,000 & Berkorelasi & 0,744 & Kuat, Positif \\
$\mathrm{H}_{3 \mathrm{a}}$ Kualitas Layanan-Kepuasan Pengguna & 0,000 & Berkorelasi & 0,780 & Kuat, Positif \\
$\mathrm{H}_{3 \mathrm{~b}}$ Kualitas Layanan-Penggunaan Sistem & 0,000 & Berkorelasi & 0,733 & Kuat, Positif \\
$\mathrm{H}_{4 \mathrm{a}}$ Penggunaan Website-Kepuasan Pengguna & 0,000 & Berkorelasi & 0,725 & Kuat, Positif \\
$\mathrm{H}_{4 \mathrm{~b}}$ Penggunaan Website-Manfaat Bersih & 0,000 & Berkorelasi & 0,607 & Sedang, Positif \\
$\mathrm{H}_{5 \mathrm{a}}$ Kepuasan Pengguna-Penggunaan Website & 0,000 & Berkorelasi & 0,725 & Kuat, Positif \\
$\mathrm{H}_{5 \mathrm{~b}}$ Kepuasan Pengguna-Manfaat Bersih & 0,000 & Berkorelasi & 0,759 & Kuat, Positif \\
$\mathrm{H}_{6 \mathrm{a}}$ Manfaat Bersih-Kepuasan Pengguna & 0,000 & Berkorelasi & 0,759 & Kuat, Positif \\
$\mathrm{H}_{6 \mathrm{~b}}$ Manfaat Bersih-Penggunaan Website & 0,000 & Berkorelasi & 0,607 & Sedang, Positif \\
\hline
\end{tabular}

Hasil pengujian hipotesis menunjukkan bahwa semua hipotesis yang diuji dalam riset ini terdukung. Adapun pembahasan dari pengujian hipotesis, antara lain sebagai berikut:

1. $\mathrm{H}_{1 \mathrm{a}}$ terdukung. Nilai sig. 0,000 dan koefisien korelasi sebesar 0,806, berarti kualitas sistem memiliki pengaruh positif dan sangat kuat terhadap kepuasan pengguna website di PT Yogyakartas Mega Grafika. Korelasi positif antara kualitas sistem dan kepuasan pengguna website menunjukkan bahwa semakin baik kualitas sistem maka semakin tinggi tingkat kepuasan pengguna dalam menggunakan website di PT Yogyakartas Mega Grafika. Demikian sebaliknya, semakin rendah kualitas sistem, maka semakin rendah tingkat kepuasan pengguna website di PT Yogyakartas Mega Grafika. Temuan riset ini sejalan dengan riset [12][14][16]. Pengguna akan merasa puas jika sistem cepat dalam menampilkan informasi yang diinginkan atau mudah dalam mengakses website melalui perangkat atau platform beragam.

2. $\mathrm{H}_{1 \mathrm{~b}}$ terdukung. Nilai sig. 0,000 dan koefisien korelasi sebesar 0,676, berarti kualitas sistem memiliki pengaruh positif dan kuat terhadap penggunaan website di PT Yogyakartas Mega Grafika. Korelasi positif antara kualitas sistem dan penggunaan website menunjukkan bahwa semakin baik kualitas sistem maka semakin tinggi penggunaan website di PT Yogyakartas Mega Grafika, demikian sebaliknya. Temuan riset ini sejalan dengan riset [12][17]. Pengguna dapat menggunakan fungsi yang ada pada website dengan baik karena didukung oleh kualitas sistem yang baik pula.

3. $\mathrm{H}_{2 \mathrm{a}}$ terdukung. Nilai sig. 0,000 dan koefisien korelasi 0,858 , berarti kualitas informasi memiliki pengaruh positif dan sangat kuat terhadap kepuasan pengguna website di PT Yogyakartas Mega Grafika. Korelasi positif antara kualitas informasi dan kepuasan pengguna website menunjukan bahwa semakin baik kualitas informasi maka semakin tinggi 
tingkat kepuasan pengguna dalam menggunakan website di PT Yogyakartas Mega Grafika. Demikian sebaliknya, semakin rendah kualitas informasi, maka semakin rendah tingkat kepuasan pengguna website di PT Yogyakartas Mega Grafika. Temuan riset ini sejalan dengan riset [12][14][16]. Pengguna akan merasa puas jika mendapatkan informasi yang lengkap, mudah dipahami dan menarik sehingga dapat mendorong pengguna untuk kembali menggunakan website.

4. $\mathrm{H}_{2 \mathrm{~b}}$ terdukung. Nilai sig. 0,000 dan koefisien korelasi 0,744, berarti kualitas informasi memiliki pengaruh positif dan kuat terhadap penggunaan website di PT Yogyakartas Mega Grafika. Korelasi positif antara kualitas informasi dan penggunaan website menunjukan bahwa semakin baik kualitas informasi maka semakin tinggi penggunaan website di PT Yogyakartas Mega Grafika, demikian sebaliknya. Temuan riset ini sejalan dengan riset [12][17][23]. Pengguna kembali menggunakan website karena telah mendapatkan informasi yang mudah dipahami serta lengkap.

5. $\mathrm{H}_{3 \mathrm{a}}$ terdukung. Nilai sig. 0,000 dan koefisien korelasi 0,780 , berarti kualitas layanan memiliki pengaruh positif dan kuat terhadap kepuasan pengguna website di PT Yogyakartas Mega Grafika. Korelasi positif antara kualitas layanan dan kepuasan pengguna website menunjukan bahwa semakin baik kualitas layanan maka semakin tinggi tingkat kepuasan pengguna dalam menggunakan website di PT Yogyakartas Mega Grafika. Demikian sebaliknya, semakin rendah kualitas layanan, maka semakin rendah tingkat kepuasan pengguna website di PT Yogyakartas Mega Grafika. Temuan riset ini sejalan dengan riset [14][16][24]. Pengguna akan merasa puas jika layanan chat customer service berfungsi dengan baik.

6. $\mathrm{H}_{3 \mathrm{~b}}$ terdukung. Nilai sig. 0,000 dan koefisien korelasi 0,733 , berarti kualitas layanan memiliki pengaruh positif dan kuat terhadap penggunaan website di PT Yogyakartas Mega Grafika. Korelasi positif antara kualitas layanan dan penggunaan website menunjukan bahwa semakin baik kualitas layanan maka semakin tinggi penggunaan website di PT Yogyakartas Mega Grafika, demikian sebaliknya. Temuan riset ini sejalan dengan riset [12][14]. Pengguna dapat menggunakan layanan chat customer service jika dibutuhkan untuk menanyakan mengenai yang hal dibutuhkan.

7. $\mathrm{H}_{4 \mathrm{a}}$ terdukung. Nilai sig. 0,000 dan koefisien korelasi 0,725 , berarti penggunaan sistem memiliki pengaruh kuat terhadap kepuasan pengguna sistem di PT Yogyakartas Mega Grafika. Korelasi positif antara penggunaan sistem dan kepuasan pengguna website menunjukan bahwa semakin baik penggunaan sistem maka semakin tinggi tingkat kepuasan pengguna dalam menggunakan website di PT Yogyakartas Mega Grafika. Demikian sebaliknya, semakin rendah penggunaan sistem, maka semakin rendah tingkat kepuasan pengguna website di PT Yogyakartas Mega Grafika. Temuan riset ini sejalan dengan riset [14][16][23]. Pengguna akan merasa puas jika saat menggunakan fungsi yang ada pada website dengan baik sehingga mendorong pengguna untuk kembali menggunakan website.

8. $\mathrm{H}_{4 \mathrm{~b}}$ terdukung. Nilai sig. 0,000 dan koefisien korelasi 0,607 , berarti penggunaan sistem memiliki pengaruh sedang terhadap dampak penggunaan website di PT Yogyakartas Mega Grafika. Korelasi positif antara penggunaan sistem dan dampak penggunaan website menunjukan bahwa semakin baik penggunaan sistem maka semakin tinggi dampak penggunaan website di PT Yogyakartas Mega Grafika, demikian sebaliknya. Temuan riset ini sejalan dengan riset [12][14]. Pengguna dapat menggunakan fungsi yang ada pada website dengan baik sehingga mempermudah dalam mendapatkan informasi tanpa harus pergi ke outlet.

9. $\mathrm{H}_{5 \mathrm{a}}$ terdukung. Nilai sig. 0,000 dan koefisien korelasi 0,725, berarti kepuasan Pengguna memiliki pengaruh kuat terhadap penggunaan website di PT Yogyakartas Mega Grafika. Korelasi positif antara kepuasan pengguna dan penggunaan website menunjukan bahwa semakin tinggi tingkat kepuasan pengguna maka semakin tinggi penggunaan website di PT Yogyakartas Mega Grafika. Demikian sebaliknya, semakin rendah tingkat kepuasan pengguna, maka semakin rendah penggunaan website di PT Yogyakartas Mega Grafika. Temuan riset ini sejalan dengan riset [14]. Pengguna akan kembali menggunakan website jika merasa puas sehingga akan mempengaruhi tingkat kunjungan di website. 
10. $\mathrm{H}_{5 \mathrm{~b}}$ terdukung. Nilai sig. 0,000 dan koefisien korelasi 0,759 , berarti kepuasan pengguna memiliki pengaruh kuat terhadap dampak penggunaan website di PT Yogyakartas Mega Grafika. Korelasi positif antara kepuasan pengguna dan dampak penggunaan website menunjukan bahwa semakin tinggi tingkat kepuasan pengguna maka semakin tinggi dampak penggunaan website di PT Yogyakartas Mega Grafika, demikian sebaliknya. Temuan riset ini sejalan dengan riset [12][14][18]. Pengguna akan terdorong untuk melakukan pembelian kembali sehingga berdampak baik terhadap penjualan produk perusahaan karena merasa puas dengan website.

11. $\mathrm{H}_{6 \mathrm{a}}$ terdukung. Nilai sig. 0,000 dan koefisien korelasi 0,759 , berarti dampak pengguna memiliki pengaruh positif dan kuat terhadap kepuasan pengguna website di PT Yogyakartas Mega Grafika. Korelasi positif antara kualitas layanan dan kepuasan pengguna website menunjukan bahwa semakin baik dampak penggunaan maka semakin tinggi tingkat kepuasan pengguna dalam menggunakan website di PT Yogyakartas Mega Grafika. Demikian sebaliknya, semakin rendah dampak penggunaan, maka semakin rendah tingkat kepuasan pengguna website di PT Yogyakartas Mega Grafika. Temuan riset ini sejalan dengan riset [14][16][17]. Pengguna akan merasa puas jika website mempermudah dalam pencarian produk sehingga pengguna akan kembali menggunakan website.

12. $\mathrm{H}_{6 \mathrm{~b}}$ terdukung. Nilai sig. 0,000 dan koefisien korelasi 0,607 , berarti dampak penggunaan memiliki pengaruh positif dan sedang terhadap penggunaan website di PT Yogyakartas Mega Grafika. Korelasi positif antara dampak penggunaan dan penggunaan website menunjukan bahwa semakin baik dampak penggunaan maka semakin tinggi penggunaan website di PT Yogyakartas Mega Grafika, demikian sebaliknya. Temuan riset ini sejalan dengan riset [14]. Pengguna dapat menggunakan website untuk mempermudah dalam pencarian produk tanpa harus datang ke outlet dengan menggunakan fungsi yang ada pada website saja.

Hasil pengujian menemukan bahwa tingkat kesuksesan sistem informasi berdasarkan model DeLone-McLean website yogyakartas.com milik PT Yogyakartas Mega Grafika terbukti sukses berperan meningkatkan kinerja perusahaan saat pandemi COVID-19. Ada dua hipotesis yang terbukti berkorelasi dengan sangat kuat dan positif, yakni kualitas sistem dengan kepuasan pengguna serta kualitas informasi dengan kepuasan pengguna. Ini artinya bahwa kualitas sistem dan kualitas informasi yang ada pada website, berperan dalam kepuasan pelanggan PT Yogyakartas Mega Grafika. Website PT Yogyakartas Mega Grafika berperan selama COVID-19, yaitu membantu memudahkan pelanggan untuk melihat katalog produk dan melakukan pemesanan tanpa harus datang ke perusahaan. Pelanggan yang puas akan kinerja dari website akan melakukan transaksi ulang karena merasa bahwa website dapat membantu menghemat biaya pencarian dan sekaligus dapat meminimalisir penyebaran virus corona karena transaksi semua dilakukan secara online, yang minim kontak fisik antara penjual dan pembeli. Penggunaan website selama pandemi di PT Yogyakartas Mega Grafika terbukti secara empiris dapat meningkatkan kinerja perusahaan. Ini sejalan dengan riset [3] bahwa penggunaan teknologi informasi dan komunikasi berupa website dapat berkontribusi untuk meningkatkan kinerja dan berdampak pada peningkatan pendapatan selama masa pandemi.

\section{Hasil Pengujian Tambahan}

Pengujian tambahan dilakukan untuk melihat konsistensi hasil pengujian yang telah dilakukan pada tahap sebelumnya. Pengujian dilakukan dengan menggunakan rumus dan perhitungan, sama seperti riset [11]. Analisis kesuksesan website PT Yogyakartas Mega Grafika selama COVID-19 dilakukan dengan menghitung bobot rata-rata item pengukuran dibagi dengan nilai skala likert yang diperoleh dari kuesioner. Hasil uji kesuksesan website PT Yogyakartas Mega Grafika disajikan pada Tabel 6. Adapun rumus dan perhitungan untuk menguji kesuksesan sebagai berikut:

a. Total rata-rata item pengukuran

$$
\text { Rata }- \text { rata item pengukuran }=\frac{(\text { skala } \times \text { Bobot skala item pengukuran })}{\text { jumlah responden }}
$$

Hasil perhitungan rata-rata item pengukuran adalah sebesar 103,23. Angka ini, kemudian digunakan untuk menghitung bobot rata-rata item pengukuran di tahap selanjutnya. 
b. Bobot rata-rata item pengukuran

c. Persentase kesuksesan

$$
\begin{gathered}
\text { Bobot rata }- \text { rata item pengukuran }=\frac{\text { total rata }- \text { rata item pengukuran }}{\text { jumlah indikator }} \\
\qquad=\frac{103,23}{25}=4,13
\end{gathered}
$$

$$
\begin{aligned}
\text { Persentase kesuksesan } & =\frac{\text { Bobot rata }- \text { rata item pengukuran }}{\text { nilai maksimal skala likert }} \times 100 \% \\
& =\frac{4,13}{5} \times 100 \%=82,6 \%
\end{aligned}
$$

\begin{tabular}{|c|c|c|c|c|c|c|c|c|}
\hline \multirow{2}{*}{ No. } & \multirow{2}{*}{ Indikator } & STS & $\mathrm{TS}$ & $\mathrm{N}$ & $\mathrm{S}$ & SS & \multirow{2}{*}{$\begin{array}{c}\text { Jumla } \\
\mathrm{h}\end{array}$} & \multirow{2}{*}{$\begin{array}{c}\text { Rata- } \\
\text { rata }\end{array}$} \\
\hline & & 1 & 2 & 3 & 4 & 5 & & \\
\hline 1 & KS1 & 1 & 0 & 4 & 27 & 34 & 66 & 4,41 \\
\hline 2 & $\mathrm{KS} 2$ & 1 & 1 & 7 & 31 & 26 & 66 & 4,21 \\
\hline 3 & KS3 & 0 & 2 & 12 & 26 & 26 & 66 & 4,15 \\
\hline 4 & KS4 & 1 & 2 & 10 & 26 & 27 & 66 & 4,15 \\
\hline 5 & KS5 & 0 & 2 & 9 & 26 & 29 & 66 & 4,24 \\
\hline 6 & KI1 & 0 & 4 & 14 & 19 & 29 & 66 & 4,11 \\
\hline 7 & $\mathrm{KI} 2$ & 0 & 2 & 12 & 27 & 25 & 66 & 4,14 \\
\hline 8 & $\mathrm{KI} 3$ & 0 & 3 & 11 & 27 & 25 & 66 & 4,12 \\
\hline 9 & KI4 & 1 & 4 & 8 & 29 & 24 & 66 & 4,08 \\
\hline 10 & KI5 & 0 & 3 & 16 & 19 & 28 & 66 & 4,09 \\
\hline 11 & KL1 & 1 & 2 & 14 & 26 & 23 & 66 & 4,03 \\
\hline 12 & KL2 & 0 & 4 & 9 & 30 & 23 & 66 & 4,09 \\
\hline 13 & KL3 & 1 & 5 & 14 & 28 & 18 & 66 & 3,86 \\
\hline 14 & $\mathrm{P} 1$ & 0 & 2 & 6 & 26 & 32 & 66 & 4,33 \\
\hline 15 & $\mathrm{P} 2$ & 0 & 0 & 12 & 28 & 26 & 66 & 4,21 \\
\hline 16 & P3 & 3 & 12 & 18 & 19 & 14 & 66 & 3,44 \\
\hline 17 & $\mathrm{P} 4$ & 9 & 14 & 15 & 12 & 16 & 66 & 3,18 \\
\hline 18 & KP1 & 1 & 4 & 13 & 25 & 23 & 66 & 3,98 \\
\hline 19 & KP2 & 1 & 3 & 16 & 24 & 22 & 66 & 3,95 \\
\hline 20 & KP3 & 0 & 2 & 10 & 19 & 35 & 66 & 4,32 \\
\hline 21 & MB1 & 0 & 2 & 4 & 25 & 35 & 66 & 4,41 \\
\hline 22 & MB2 & 0 & 1 & 7 & 22 & 36 & 66 & 4,41 \\
\hline 23 & MB3 & 0 & 1 & 8 & 21 & 36 & 66 & 4,39 \\
\hline 24 & MB4 & 0 & 1 & 7 & 19 & 39 & 66 & 4,45 \\
\hline 25 & MB5 & 1 & 0 & 5 & 22 & 38 & 66 & 4,45 \\
\hline \multicolumn{8}{|c|}{ Total rata-rata item pengukuran } & 103,23 \\
\hline
\end{tabular}

Tabel 6. Hasil Uji Kesuksesan

Hasil pengujian tambahan menemukan bahwa bobot rata-rata item pengukuran sebesar 4,13 dan hasil persentase kesuksesan adalah 82,6 persen. Ini artinya bahwa website PT Yogyakartas Mega Grafika dinyatakan sangat sukses digunakan saat COVID-19. Pengujian tambahan ini memperkuat temuan bahwa penggunaan website di PT Yogyakartas Mega Grafika memiliki pengaruh pada peningkatan kinerja perusahaan saat COVID-19 berlangsung. Pelanggan PT Yogyakartas Mega Grafika masih dapat melakukan pemesanan produk lewat website, meskipun kebijakan pembatasan sosial skala besar diberlakukan untuk meminimalkan penyebaran virus corona. Oleh sebab itu, perusahaan perlu terus melakukan pengelolaan sistem informasi agar dapat memperoleh manfaat maksimal dari penggunaannya untuk menunjang kegiatan operasional perusahaan.

\section{Kesimpulan}

Riset ini memberikan bukti empiris bahwa penggunaan website di PT Yogyakartas Mega Grafika saat pandemi COVID-19 sukses berperan meningkatkan kinerja perusahaan. Model DeLone-McLean dapat digunakan untuk mengukur tingkat kesuksesan website di PT Yogyakartas Mega Grafika. Riset ini menemukan website membantu memudahkan pelanggan untuk melihat katalog produk dan 
melakukan pemesanan tanpa harus datang ke perusahaan. Pelanggan yang puas akan kinerja dari website akan melakukan transaksi ulang karena merasa bahwa website dapat membantu menghemat biaya pencarian dan sekaligus dapat meminimalisir penyebaran virus corona karena transaksi semua dilakukan secara online, yang minim kontak fisik antara penjual dan pembeli. Temuan ini juga kokoh dalam analisis tambahan dengan menghitung bobot rata-rata item pengukuran dibagi dengan nilai skala likert. Hasil riset menemukan bahwa bobot rata-rata item pengukuran sebesar 4,13 dan hasil persentase kesuksesan adalah 82,6 persen. Ini artinya website PT Yogyakartas Mega Grafika dinyatakan sangat sukses digunakan meningkatkan kinerja perusahaan selama pandemi COVID-19.

Riset ini memiliki keterbatasan berkaitan dengan jumlah responden. Tingkat pengembalian kuesioner dalam riset ini rendah karena kuesioner survei terkait kesuksesan tidak dilekatkan pada website PT Yogyakartas Mega Grafika. Dalam riset, ukuran sampel yang besar diperlukan untuk mendapatkan tingkat keterwakilan populasi [25]. Oleh sebab itu, riset yang akan datang diharapkan dapat lebih memperbanyak jumlah responden yang mengisi kuesioner dengan cara melekatkan kuesioner untuk mengevaluasi kesuksesan penggunaan sistem informasi pada website PT Yogyakartas Mega Grafika.

\section{Referensi}

[1] Pusat Penelitian Ekonomi LIPI, "Suvei LIPI: 94 Persen Penjualan UMKM Turun," Lembaga Ilmu Pengetahuan Indonesia, 2020. .

[2] E. Maria, "Digitalisasi Ekonomi Desa Memasuki Era Kenormalan Baru," in Perkembangan Perekonomian Indonesia saat Serangan Pandemi Covid-19, vol. 1, no. 9, T. C. Leasiwal, Ed. Serang Banten: CV. AA. Rizky, 2020, pp. 25-58.

[3] E. Maria, S. Suharyadi, and R. K. Hudiono, "Implementasi pemasaran digital berbasis website sebagai strategi kenormalan baru Dusun Srumbung Gunung pasca Covid-19," Riau J. Empower., vol. 4, no. 1, pp. 1-10, 2021, doi: 10.31258/raje.4.1.1-10.

[4] K. C. Laudon and J. P. Laudon, Management Information Systems: Managing the Digital Firm, 12th editi., vol. 7, no. 1. Pearson Prentice Hall, 2012.

[5] J. E. Bailey and S. W. Pearson, "Development of a Tool for Measuring and Analyzing Computer User Satisfaction," Manage. Sci., vol. 29, no. 5, pp. 530-545, 1983, doi: http://dx.doi.org/10.1287/mnsc.29.5.530.

[6] W. H. DeLone and E. R. McLean, "The DeLone and McLean model of information systems success: A ten-year update," J. Manag. Inf. Syst., vol. 19, no. 4, pp. 9-30, 2003, doi: 10.1080/07421222.2003.11045748.

[7] P. B. Seddon, "Respesification and Extension of The DeLone and Mc Lean Model of IS Success," Inf. Syst. Res., vol. 8, no. 3, pp. 240-253, 1997.

[8] A. Rai, S. S. Lang, and R. B. Welker, "Assessing the Validity of IS Success Models: An Empirical Test and Theoretical Analysis," Inf. Syst. Res., vol. 13, no. 1, pp. 29-34, 2002, doi: 10.1287/isre.13.1.50.96.

[9] H. Laksono, "Evaluasi Kesuksesan Simda Bmd Pada Pemerintah Kabupaten Grobogan Menggunakan Model Kombinasi Delone Mclean Dan Technology Acceptance Model," J. Tata Kelola Akuntabilitas Keuang. Negara, vol. 3, no. 2, p. 151, 2017, doi: 10.28986/jtaken.v3i2.101.

[10] P. H. Saputro, A. D. Budiyanto, and A. J. Santoso, "Model Delone and Mclean untuk Mengukur Kesuksesan E-government Kota Pekalongan," vol. 2, no. 1, pp. 1-8, 2015.

[11] R. Rachman, "Analisa Kesuksesan E - Government LAPOR dengan Model Delone - Mclean pada Pengembangan Smart City," Sist. J. Sist. Inf., vol. 10, pp. 357-368, 2021.

[12] R. K. L. Wiyati and N. L. K. Y. Sarja, "Evaluasi Kesuksesan Sistem Informasi Absensi Online Menggunakan Model Delone Mclean," J. Media Apl., vol. 10, no. 2, pp. 135-157, 2018.

[13] C. Tam and T. Oliveira, "Understanding mobile banking individual performance: The DeLone \& McLean model and the moderating effects of individual culture," Internet Res., vol. 27, no. 3, pp. 538-562, 2017, doi: 10.1108/IntR-05-2016-0117.

[14] T. Tarwoto and A. P. Kuncoro, "Evaluasi Penerapan Sistem Informasi Smart Prodi dengan Pendekatan Delone Mclean dan Framework Cobit 5," MATRIK J. Manajemen, Tek. Inform. dan Rekayasa Komput., vol. 18, no. 2, pp. 222-236, 2019, doi: 10.30812/matrik.v18i2.367.

[15] A. D. Herlambang, S. H. Wijoyo, A. Rachmadi, C. Felita, and N. Alimah, "Criteria-Based http://sistemasi.ftik.unisi.ac.id 
Evaluation for Health Information System Implementation Success Based on Delone and Mclean Model," J. Teknol. Inf. dan Ilmu Komput., vol. 6, no. 3, pp. 315-320, 2019, doi: 10.25126/jtiik.201961321.

[16] G. A. A. Wisudiawan, "Analisis faktor kesuksesan sistem informasi menggunakan model delone and mclean," J. Ilm. Teknol. Inf. Terap., vol. 2, no. 1, pp. 55-59, 2015.

[17] M. Al Farizi, "Model Kesuksesan Sistem Informasi Delone dan Mclean Untuk Mengukur Kesuksesan Sistem Modernisasi Perpajakan E-Billing Menurut Wajib Pajak Kota Semarang," J. Monex, vol. 7, pp. 373-375, 2018.

[18] T. Y. Rachmadi and R. D. Handaka, "Evaluasi Penerapan E-Faktur Dengan Model Kesuksesan Sistem Informasi Delone Dan Mclean (Studi Kasus Di Kpp Pratama Metro)," Substansi Sumber Artik. Akunt. Audit. dan Keuang. Vokasi, vol. 3, no. 2, p. 129, 2019, doi: 10.35837/subs.v3i2.580.

[19] Suryana, "Metodologi Penelitian : Metodologi Penelitian Model Prakatis Penelitian Kuantitatif dan Kualitatif," Univ. Pendidik. Indones., pp. 1-243, 2012, doi: 10.1007/s13398-014-0173-7.2.

[20] M. N. Yakubu and S. I. Dasuki, "Assessing eLearning systems success In Nigeria: An application of the Delone And Mclean information systems success model," J. Inf. Technol. Educ. Res., vol. 17, pp. 183-203, 2018, doi: 10.28945/4077.

[21] B. Susetyo, Statistika Untuk Analisis Data Penelitian: dilengkapi cara perhitungan dengan SPSS dan MS Office Excel. Refika Aditama, 2014.

[22] Sugiyono, Statistika untuk Penelitian. Bandung: CV Alfabeta Bandung, 2017.

[23] A. N. Celine Aloyshima Haris, Bambang Soedijono WA, "Evaluasi Aplikasi Ruang Guru Menggunakan Model UTAUT2 dan Model Kesuksesan DeLone and McLean," J. Tek. dan Inov., vol. 4, no. 1, pp. 1-9, 2020.

[24] L. T. Utomo, Y. T. Ardianto, and N. Sisharini, "Pengaruh Kualitas Sistem, Kualitas Informasi, Kualitas Layanan, Terhadap Kepuasan Pengguna Sistem Informasi Akademik Universitas Merdeka Malang," J. Teknol. dan Manaj. Inform., vol. 3, no. 2, 2017, doi: 10.26905/jtmi.v3i2.1425.

[25] A. Adib Abadi, "Problematika Penentuan Sampel Dalam Penelitian Bidang Perumahan Dan Permukiman," Dimens. (Jurnal Tek. Arsitektur), vol. 34, no. 2, pp. 138-146, 2006, [Online]. Available: http://puslit2.petra.ac.id/ejournal/index.php/ars/article/view/16546. 